\title{
DESIGN AND IMPLEMENTATION OF A TRAINING SET FOR DISTRIBUTED SYSTEM AND MECHATRONIC APPLICATIONS: PROJECT BASED LEARNING
}

\author{
Mehmet Fatih Ișik
}

Orginal scientific paper Nowadays, with the development of information technology, real-time and reliable devices have been developed for users and system control. Commonly used ones are programmable logic controller and operator panels. Programming of these devices, learning the communication with the controller and the hardware installations have gained great importance especially for technical staff and engineering students. In this study, automation and control technique training sets were developed for the applications used widely in industrial applications. In the training sets, programmable logic controller (PLC) and human machine interface (HMI) were used for the control. With the training sets both automation education and control techniques such as P, PI, and PID are compared. At the same time, skills and logical programming abilities of the students studying in the training were attempted to be improved with this application. In order to measure and evaluate, 18 technical staff working in the industrial sector, 14 students studying automation engineering and eight students studying pre-license training, a group of 40 people in total was formed and performances were measured at the end of the training.

Keywords: automation; distributed system; servo systems, training set

\section{Oblikovanje i implementacija seta za učenje za primjenu na distribuiranom sustavu i mehatronici: učenje na temelju projekta}

Izvorni znanstveni članak

Danas, s razvojem informatičke tehnologije, razvijeni su suvremeni i pouzdani uređaji za korisnike i upravljanje sustavom. Najviše korišteni su paneli za operatera i regulatori logike za programiranje. Programiranje ovih uređaja, učenje kako komunicirati s kontrolnim i hardverskim instalacijama postalo je vrlo važno posebice za tehničko osoblje i studente inženjerstva. U ovom radu, razvijeni su setovi za učenje tehnika za automatizaciju i upravljanje koji se uvelike rabe u industrijskim aplikacijama. U tim su se setovima za upravljanje koristili regulator logike za programiranje (PLC) i sučelje između čovjeka i stroja - human machine interface (HMI). U setovima za učenje paralelno su se uspoređivale i uvježbavale tehnike automatizacije i regulacije kao P, PI PID. U isto vrijeme, s tom su se aplikacijom pokušavale popraviti vještine i sposobnosti logičkog programiranja obučavanih studenata. U svrhu mjerenja i evaluacije, formirana je grupa od 40 ljudi - 18 pripadnika tehničkog osoblja iz industrijskog sektora, 14 studenata inžinjerstva automatizacije i 8 studenata pripremanih za rad prije stjecanja diplome, čije su se sposobnosti mjerile po završetku obuke.

Ključne riječi: automatizacija; distribuirani sustav; servo sustavi; set za učenje

\section{Introduction}

Automatic control systems are the basis of many structures used in industrial applications. The main purpose of the automatic control system is automatic usage of the process after the user's control. The control is based on the principle of moving the mechanical systems with electric motors. Even though electric machines show differences in structure, all of them convert electrical energy to mechanical energy [1]. For the control used in the industrial control systems, all electric engines may not be suitable. In this case, depending on the size to be controlled, a proper motor selection must be made. While step motor or servomotors are usually used in the applications in which position control is needed, in many applications, asynchronous motors are preferred. Asynchronous motors are the most used electric motors in industry because of their simple structure, low cost and low maintenance need. Asynchronous motors are manufactured in 1-phase and 3-phase [2]. The usage of 70 $\%$ of the energy produced in the world on these motors shows their importance and usage frequency [3]. Single phase asynchronous motors are widely used in home appliances [4].

One of the biggest problems of countries trying to take steps towards industrialization is the setting up of the automation and the lack of staff who can intervene in case of any problems while at the same time checking and setting up the automation system. A special learning environment was created by gathering participants at an industrial college and engineering students. In addition to theoretical training, skills training education for practical purposes was also given to the trainees.

Various academic studies have been performed related to mechatronic applications and significantly successful results have been obtained [5, 6]. Among these studies, applications related to electrical machines and their controls $[7 \div 13]$, which may provide contributions to engineering education, coincide in the literature. In addition, virtual lab applications are also very prevalent.

In today's world, asynchronous motors are used much more commonly to meet electro-mechanical energy needs. The disadvantage of AM when compared to Direct Current (DA) motors is that they require complex control and transformation algorithms. The reason for this is that the machine has a nonlinear structure. Developments in power electronics have made the semi-conductor circuit elements with high current and high voltage available as reliable and economically beneficial. Thus in a very wide power range, it is possible to produce frequency and voltage adjustable systems which are needed for the speed and moment control of the AM. Nowadays, AM's are controlled by microprocessor-controlled power electronics circuits. Use of automation systems is considered to be one of the methods used to increase the speed and quality of production in industry. The network is an important component in automation systems. Many different network structures are used in these systems [1]. 


\section{Materials and methods}

\subsection{Human Machine Interface (HMI) and Programmable Logic Controller (PLC)}

Programmable logic controller (PLC) is an intelligent device used to perform command and control circuits of industrial automation systems [14]. PLC is also an important control unit automatically running the program posted in the internal structure according to the user requirements. Depending on the developed technology, PLCs have started to be used widely in industrial automation circuits. Today's PLCs also contain commands for making arithmetic and special mathematical operations in addition to logic-based transactions. As a result of the expansion of the command set, more complex command and control functions are performed [15]. HMI are touch screens, through which users can control the system, used widely in industrial applications. They are also referred to as a kind of minicomputer. In this study, in order to provide user control, an NB series Omron brand operator panel was used and training was provided. The developed training sets have PLC-based and HMI control; the flow diagram of the training sets is given in Fig. 1.

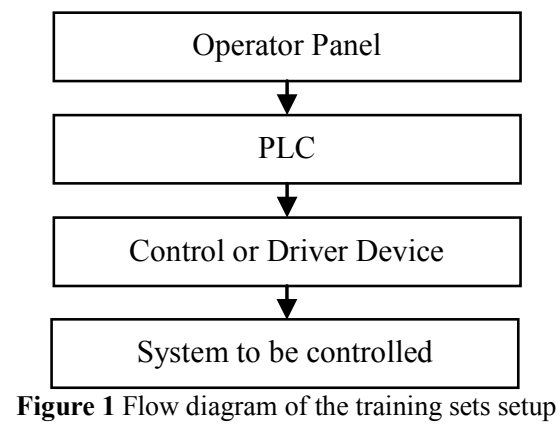

In order to develop the software of the operator panel, the algorithm in PLC used as a controller must be completed. Addressed data suitable to the developed algorithm and the addresses at which these data can be reached must be defined. Software developed as objectoriented by using operator panel software was installed in the internal memory of the operator panel through a USB port. Omron NB-Designer program suitable for the hardware was used for the software of the operator panel. An important feature of NB-Designer program is that it can run simulations.

\subsection{Installation of experiment sets}

Due to the frequent use of electrical machines in industrial applications, it is important for students studying in these areas to master the subject. Solving problems about the systems they might encounter for graduate students and the staff working in this area is possible with education [16].

Industrial control systems are used in every aspect of our daily lives, mainly in materials handling and formation machines. Knowing the working principles of electrical machines, obtaining their characteristics, and understanding the reactions in various load and working conditions are extremely important. For this reason, faculty members teaching in the field of industrial control systems should support theoretical education with practical experiments. The quality of the education given to students about this subject can be achieved by practical knowledge transfer in addition to intense theoretical knowledge. Supporting the theoretical knowledge given in education with the application increases the stability in education [17]. Students must have the choice of how they can learn with an intense education and test opportunity as well as their own learning styles [18].

Considering the current control systems, versatile, sophisticated and easy to understand training sets are needed in order to teach these subjects. Training sets are available in control systems in the commercial sense. In these training sets, alternative current (AC) or direct current (DC) motors are used and one-way position and speed controls are performed. In addition, these types of training sets are based on developing hardware and software running this hardware; one-way control was provided by using operator control panel or computer. For the motors used in this study, speed control depending on the user's requirement, position control, directional control and automatic working mechanism have been formed. In addition to these, control techniques such as P, PI and PID and stability of the control systems are described.

\subsection{Three phase asynchronous motor setup and test results}

For 3-phase asynchronous motors, speed, rotation and torque control applications can be made. With the training set, a flexible structure where control methods such as P, PI and PID can be used was established. The training set about which education was given and the HMI control units are shown in Fig. $2 \mathrm{a}$ and $2 \mathrm{~b}$.

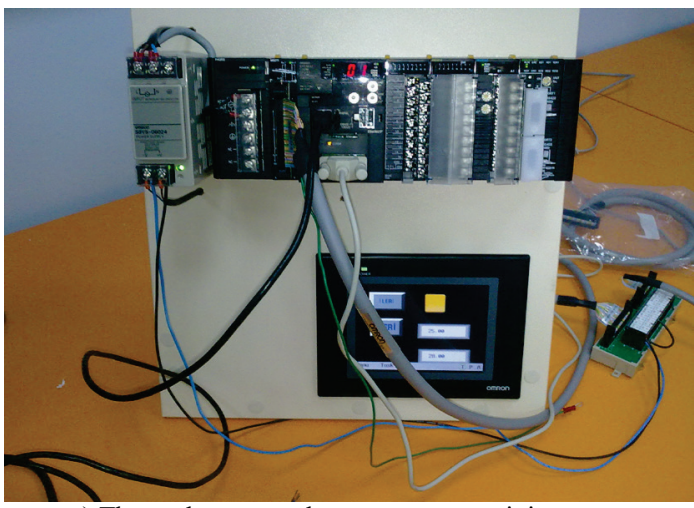

a) Three-phase asynchronous motor training setup

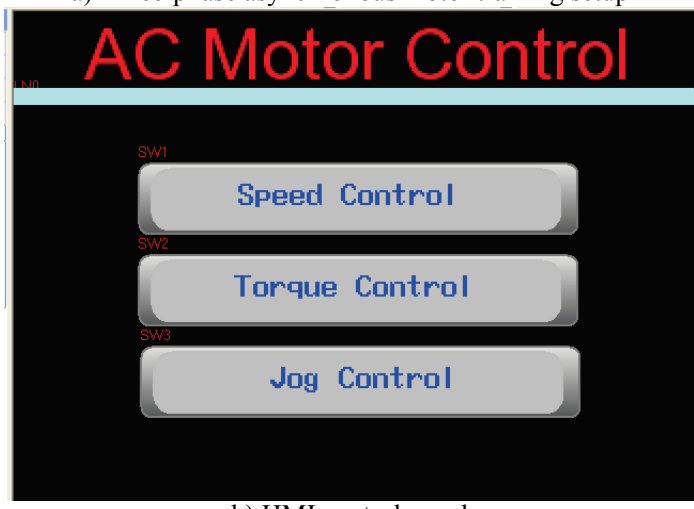

b) HMI control pane

Figure 2 AC motor training set 
Block diagram of training set developed for the applications of three-phase asynchronous motor is given in Fig. 3.

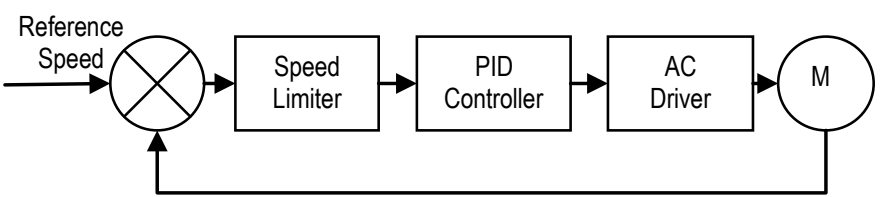

Figure 3 Block diagram of sensor less asynchronous motor control

Stator phase currents obtained by using Vissim program, speed and torque graphs are given in Figs. 4, 5, 6 and 7 , respectively.

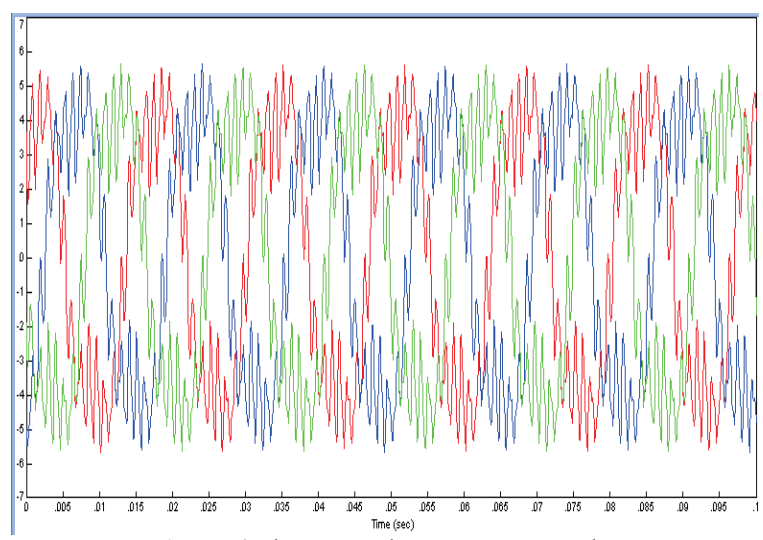

Figure 4 The stator phase currents graph

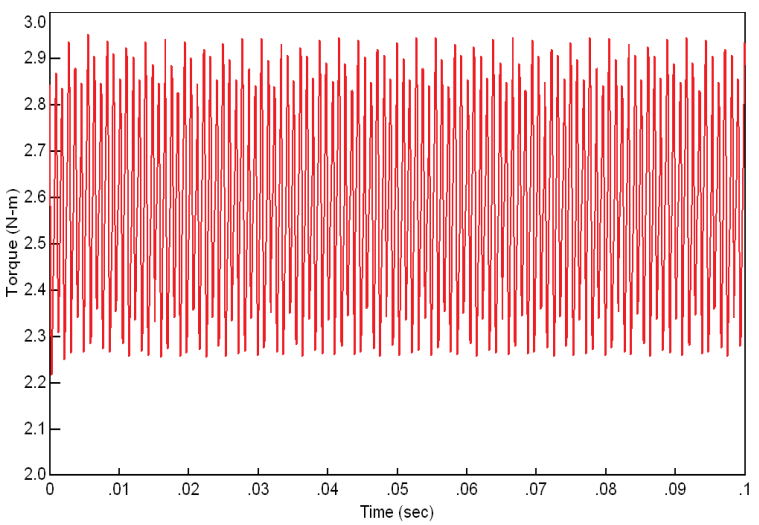

Figure 5 Torque graph

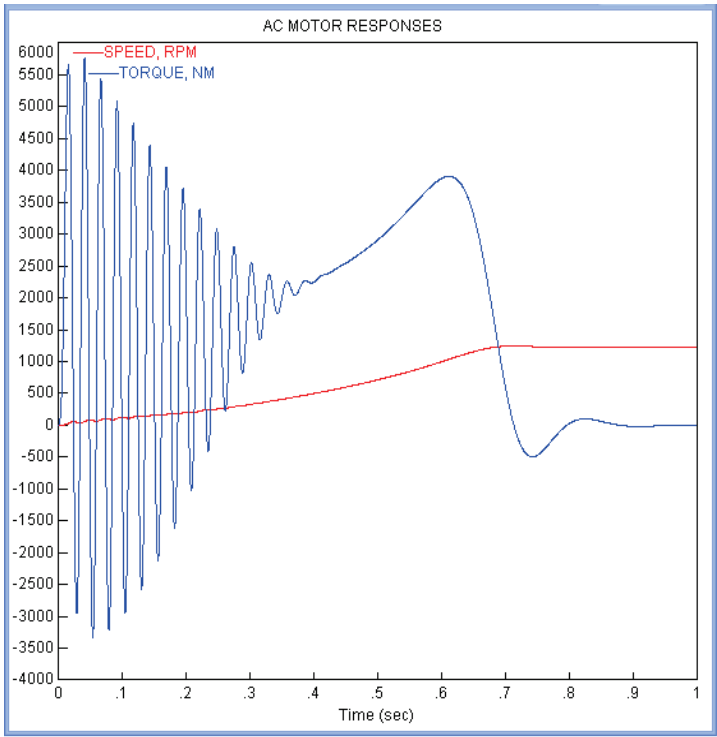

Figure $6 \mathrm{AC}$ motor speed and torque graph (t-domain)

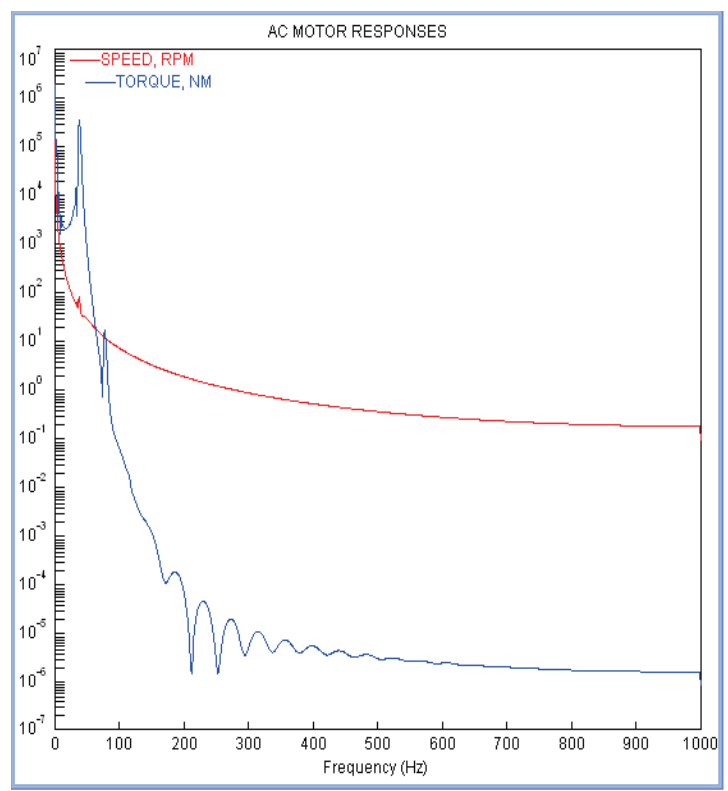

Figure $7 \mathrm{AC}$ motor speed and torque graph (z-domain)

\subsection{Servomotor test setup and test results}

With the servomotor training set, a structure which can achieve the control of position, speed and direction was formed. By using PID function located in Omron CX-Programmer software, the effects of control techniques have been investigated. Measurements depending on the operating mode of the servomotor were performed using P, PI and PID control techniques on servo control system. With Proportional gain $\left(K_{\mathrm{p}}\right)$, Integral gain $\left(K_{\mathrm{i}}\right)$ and differential gain $\left(K_{\mathrm{d}}\right)$ parameters, the most appropriate step response was attempted.

Speed, position and torque control model developed for servomotor experimental set is shown in Fig. 8.

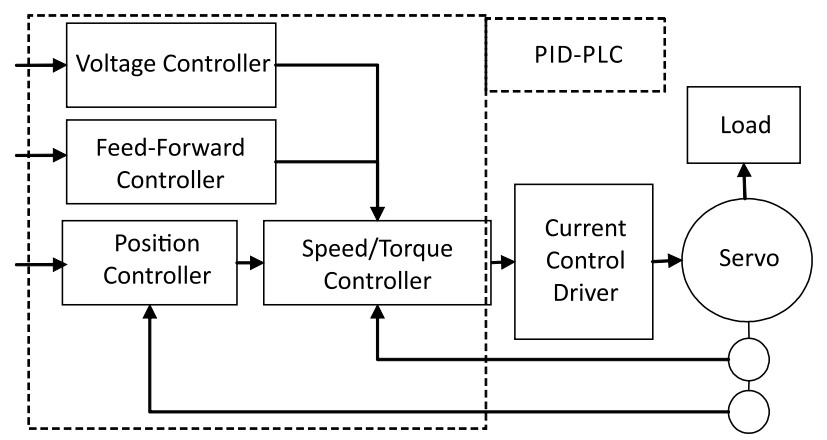

Figure 8 Servomotor control block diagram

The purpose of motor speed control by close circuit system is to adapt the output magnitude to the desired reference value. In servomotor surveillance, speed and position information can be obtained by tachometer, encoder or potentiometer from the motor shaft $[19 \div 21]$. In this study, feedback was achieved by encoder.

As the hardware unit of the servomotor control experiment set, servomotor, driver, PLC, HMI and computer are present. In the software unit the software for realization of PLC, HMI and SCADA application is present.

Servomotor experimental set and screenshot of HMI control panel are shown in Figs. 9a and 9b. 


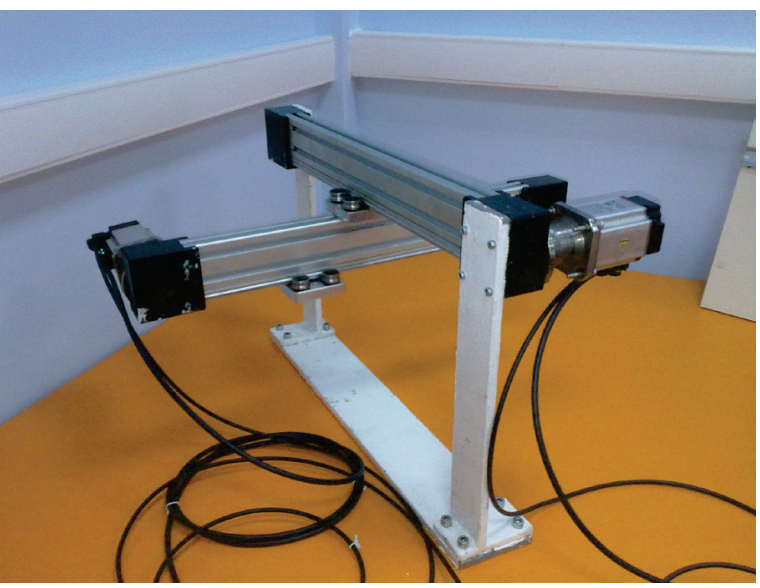

a) Servomotor test setup
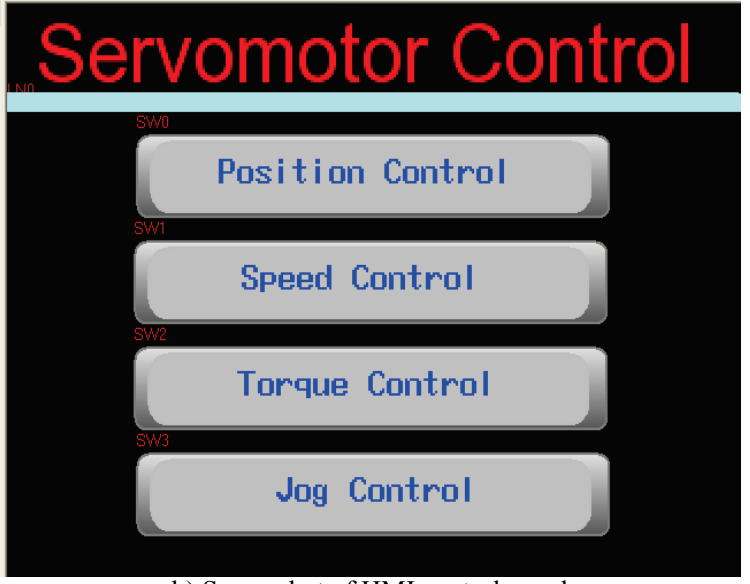

b) Screenshot of HMI control panel

Figure 9 Servomotors training set

Servomotor technical properties are shown in Tab. 1.

Table 1 Servomotor technical properties

\begin{tabular}{|c|c|c|}
\hline \multicolumn{3}{|c|}{ Servomotor } \\
\hline \multicolumn{2}{|c|}{ Nominal power } & $400 \mathrm{~W}$ \\
\hline \multicolumn{2}{|c|}{ Nominal torque } & $1,3 \mathrm{~N} \cdot \mathrm{m}$ \\
\hline \multicolumn{2}{|c|}{ Nominal speed } & $3000 \mathrm{r} / \mathrm{min}$ \\
\hline \multicolumn{2}{|c|}{ Maximum rotation speed } & $6000 \mathrm{r} / \mathrm{min}$ \\
\hline \multicolumn{2}{|c|}{ Maximum torque } & $3,8 \mathrm{~N} \cdot \mathrm{m}$ \\
\hline \multicolumn{2}{|c|}{ Nominal current } & $2,4 \mathrm{~A}(\mathrm{rms})$ \\
\hline \multicolumn{2}{|c|}{ Maximum current } & $10,2(0-p)$ \\
\hline \multirow[t]{2}{*}{ Rotor Inertia } & $\begin{array}{l}\text { Without } \\
\text { brake }\end{array}$ & $0,26 \times 10^{-4} \mathrm{~kg} \cdot \mathrm{m}^{2}$ \\
\hline & With brake & $0,28 \times 10^{-4} \mathrm{~kg} \cdot \mathrm{m}^{2}$ \\
\hline \multirow{2}{*}{$\begin{array}{l}\text { Mechanical time } \\
\text { constant }\end{array}$} & $\begin{array}{l}\text { Without } \\
\text { brake }\end{array}$ & $0,43 \mathrm{~ms}$ \\
\hline & With brake & $0,46 \mathrm{~ms}$ \\
\hline \multicolumn{2}{|c|}{ Electrical time constant } & $3,4 \mathrm{~ms}$ \\
\hline
\end{tabular}

In the servomotor control system, three different position options are presented. The first one of these is to move in the current position; for example, let us say servomotor moved $20^{\circ}$, if the user wants it to move $12^{\circ}$, then the servomotor will be moved with a total angle of $42^{\circ}$. The second case is done by moving servomotor to the home position. For example, assuming that the servomotor moved $12^{\circ}$, when the user wanted it to move $22^{\circ}$, then servomotor comes to the home position first and it moves a total of $22^{\circ}$. The last position is the angular control done according to the current situation. With this option, the user enters the desired angles step by step to the servo. For example, the user first decides whether he/she wants to bring the servo in the home position or not. If the user wants it in the home position, it comes to the point which is accepted as the starting point automatically. After this decision, the user can position the servo by entering many step values such as $1^{\circ}$ for step $1,5^{\circ}$ for step $2,4^{\circ}$ for step 3 etc. If the home position was not chosen, first position values are obtained by summing the current position and the value entered in the first step, the next steps continue by adding them to the previous position value. In this way, the user can pose a prescription for the position of the servo. Driving circuit depending on the position values that the user entered in all three options is given in Fig. 10.

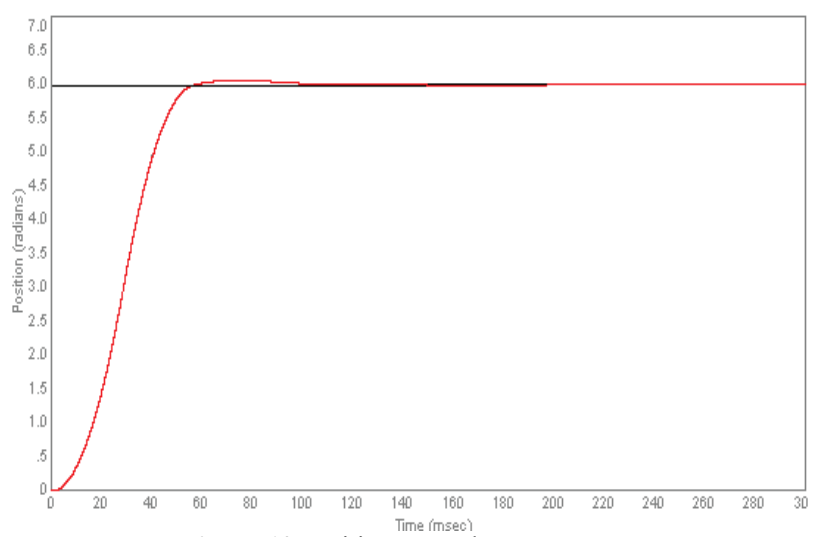

Figure 10 Position control step responses

One of the most important factors used in servomotor systems is to ensure the motor goes to the desired position with the desired speed in the fastest time. In order to reduce the settling and excess times, many control algorithms are applied. In the training sets, P, PI and PID control methods were applied to the servomotor to minimize these times and to show the time differences between the control techniques. Proportional controllers have the effect of reducing the rise time, but they cannot eliminate it completely (the steady-state error). Integra controller $\left(K_{\mathrm{i}}\right)$ has an effect on deriving steady state error but this may cause poorer transient response. Differential control $\left(K_{\mathrm{d}}\right)$ has an effect on the increase of system stability; it reduces the overshoot and improves the transient response.

These corrections are not exactly valid, because $K_{\mathrm{p}}$, $K_{\mathrm{i}}$ and $K_{\mathrm{d}}$ are dependent on each other. In other words, change of one of the variables might change the effect of the other two. Therefore, the table is a reference in order to determine the values of $K_{\mathrm{i}}, K_{\mathrm{p}}$ and $K_{\mathrm{d}}$ [22]. The example of PID controller usage in PLC is shown in Fig. $11[23]$.

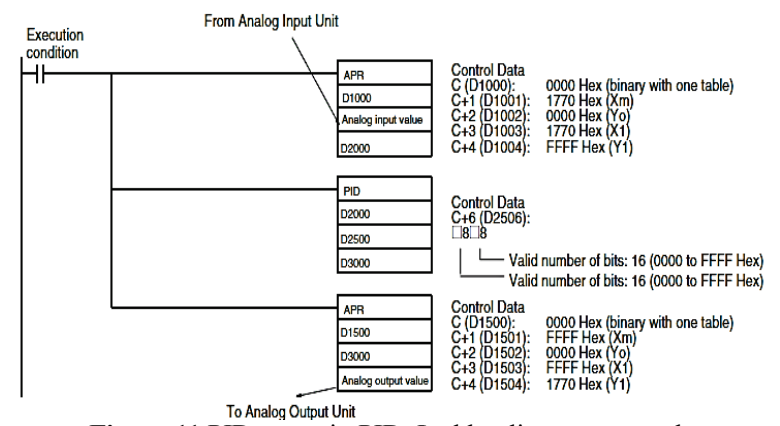

Figure 11 PID usage in PID, Ladder diagram example 
PID parameters can be manually adjusted or automatically adjusted through the auto tuning option, which can be selected from the PID parameter adjustment menu placed on the operator panel. PID adjustment window menu is shown in Fig. 12. User has the opportunity to change (numerically) the $K_{\mathrm{p}}, K_{\mathrm{i}}$ and $K_{\mathrm{d}}$ values of PID parameters. Also, the user has the opportunity to change acceleration and deceleration time values in the same window.

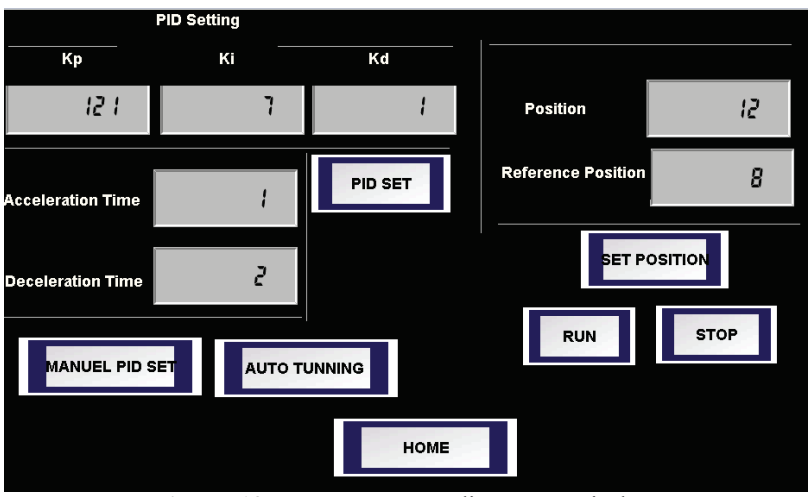

Figure 12 PID parameter adjustment window

Unit step response of Proportional control (P), Proportional-Integral (PI) and Proportional-IntegralDifferential (PID) controls used in the servomotor control are presented in Figs. 13, 14 and 15, respectively. In addition, unit step response depending on different values of P-, I and D parameters are shown in Fig. 16.

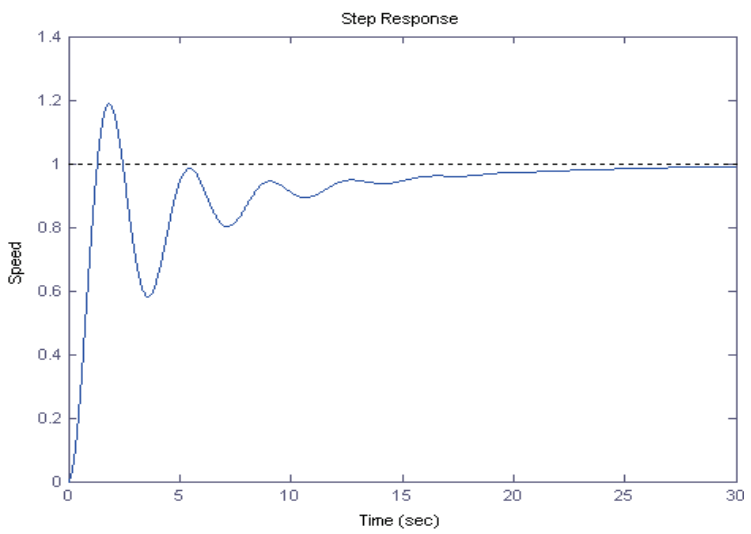

Figure 13 P Control

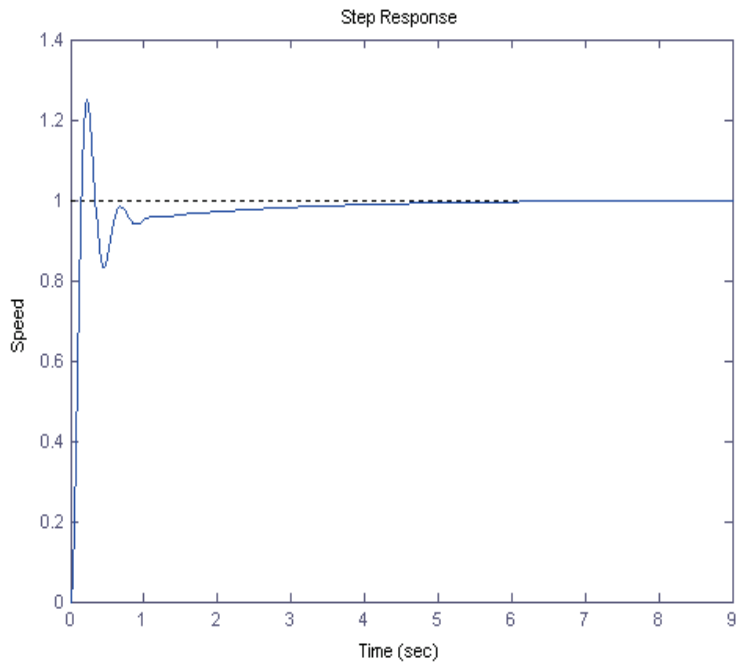

Figure 14 PI Control

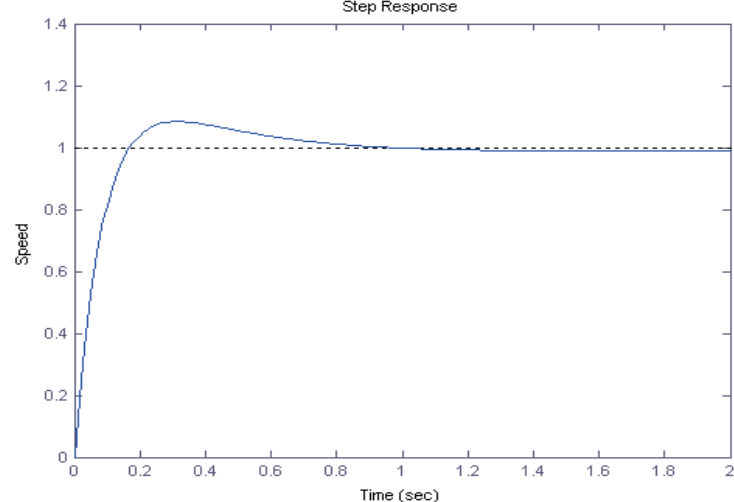

Figure 15 PID Control

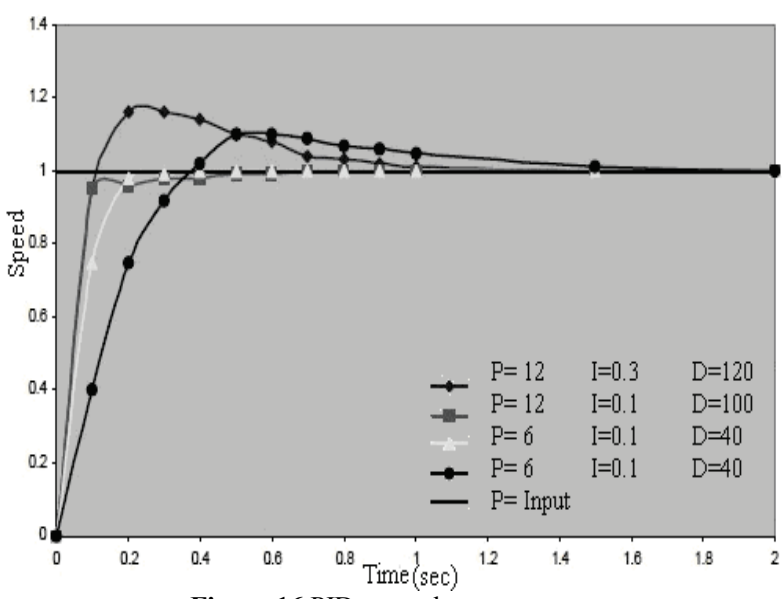

Figure 16 PID control step responses

\section{Advantages of the training set}

The advantages of the developed training set are as follows;

Since the training sets can be controlled and used in a very versatile way, many applications can be done.

Checking process can be achieved through the network with the training set.

Learning can be improved by animation and simulation techniques.

It has an active learning module as a result of the online simulation feature of PLC and HMI.

It is possible to update the training set software without any hardware change.

\section{Overview and comparison}

While education sets are designed, a structure is aimed at where frequently used motors will be checked and distributed systems will be checked as well. For the study, Omron brand PLC, driver and motors were preferred. Especially in the control of intensely precise processing benches, providing feedback and performing surveillance operations and accordingly producing algorithms bring pressure on users. As also mentioned in the aim of this study, creating a mathematical model in programs such as Matlab in order to obtain the optimum control parameters in speed, location and torque control applications of motors having the ability of precise working such as servomotors is obligatory. Thanks to this education set, trainees solved this problem easily.

The most important property which separates this 
study from others is that these types of experiment sets are generally produced separately and many trials are made on the experiment sets in order to obtain control parameters. In this study, the proposed experiment sets and control parameters were obtained by various methods and real time information was conveyed to the system. Accordingly, PID parameters, auto tuning or manual tuning opportunities have been provided for servomotor or asynchronous motor applications. A single structure has been created for asynchronous and servomotor applications, which are two types of motors that are widely used in industrial applications. This also constitutes a new experiment set developed for distributed systems. Considering the education set functionally, initially a common platform was formed for mechatronic applications and the functions of four or five education sets were redounded to single set. The applications that can be performed with these education sets can be summarized as follows:

Studies related to PLC programming, SCADA project preparation, program simulation, digital input/output applications, analog input/output applications, installation applications, on/off control, regulation and monitoring of servomotor parameters, loaded/unloaded speed, position and torque control and monitoring of servomotors, regulation and monitoring of asynchronous motor parameter values and loaded/unloaded speed, position and torque control and monitoring of asynchronous motors. On the user side, all mechanisms that can be observed in industrial applications are present for these surveillance systems. These are HMI, SCADA and control through PC. When these properties are examined, considering that the prices of current education sets are between USD10,000 - USD15,000 depending on their functions, the developed education set costs almost half this amount. This proves that the education set is economically superior as well.

Another important dimension of this study is that groups having different education levels and groups that are employed in or have education in the mechatronic field have been gathered. When national and international studies about education are examined, it is observed that studies have been focused and evaluated on a single group. Thanks to this course, the interaction of the trainees in three different groups played an important role in the success of the course. The education period being four months is another important detail of this study. Generally, this kind of course lasts a maximum of one week, special applications are explained and an increase in hand skills is not expected. On the other hand, considering as academic education, the fact that this education will last for years is also a disadvantage. For this reason, the study is considered to be one of the concrete steps in university-industry cooperation in terms of the variety of trainee groups and property of education periods.

\section{Measurement and evaluation}

A group which consisted of 18 technical staff working in the industrial sector, 14 undergrad engineering students and eight community college students was formed. A 4-month training program was applied to this group. In addition to the theoretical education given through training, applications also had an important place. At the end of the training, the questions shown in Table II were asked and a measurement-evaluation was performed.

Table 2 End of training survey for trainees

\begin{tabular}{|c|c|c|c|}
\hline \multirow[b]{2}{*}{ Opinions } & \multicolumn{3}{|c|}{ Trainees feedback } \\
\hline & $\begin{array}{l}\text { Completely } \\
\text { agree } \\
(\%)\end{array}$ & $\begin{array}{l}\text { Partially } \\
(\%)\end{array}$ & $\begin{array}{l}\text { Disagree } \\
(\%)\end{array}$ \\
\hline Course duration adequacy & 84 & 12 & 4 \\
\hline $\begin{array}{l}\text { Suitability of the course content to } \\
\text { the application }\end{array}$ & 87 & 13 & 0 \\
\hline $\begin{array}{l}\text { Adequacy of the equipment and } \\
\text { the documents for effective and } \\
\text { efficient application of the course } \\
\text { program }\end{array}$ & 92 & 8 & 0 \\
\hline $\begin{array}{l}\text { Presentation of the subject with } \\
\text { the appropriate methods and } \\
\text { techniques }\end{array}$ & 93 & 6 & 1 \\
\hline Effective and efficient use of time & 90 & 5 & 5 \\
\hline $\begin{array}{l}\text { Teaching the subjects is clear, } \\
\text { understandable and appropriate to } \\
\text { the level of the participants }\end{array}$ & 86 & 8 & 6 \\
\hline $\begin{array}{l}\text { Informing the participants about } \\
\text { finding the information and using } \\
\text { the related sources }\end{array}$ & 78 & 18 & 4 \\
\hline $\begin{array}{l}\text { Motivation and communication } \\
\text { skills }\end{array}$ & 82 & 10 & 8 \\
\hline $\begin{array}{l}\text { Associating the course content } \\
\text { with the current issues and studies }\end{array}$ & 98 & 1 & 1 \\
\hline $\begin{array}{l}\text { Associating the course contents } \\
\text { with the course participants' work } \\
\text { area }\end{array}$ & 90 & 5 & 5 \\
\hline $\begin{array}{l}\text { The course provided a positive } \\
\text { contribution to the development of } \\
\text { my abilities }\end{array}$ & 89 & 6 & 5 \\
\hline $\begin{array}{l}\text { The course has given me new } \\
\text { knowledge and skills }\end{array}$ & 96 & 4 & 0 \\
\hline $\begin{array}{l}\text { The course improved my } \\
\text { motivation }\end{array}$ & 87 & 9 & 4 \\
\hline $\begin{array}{l}\text { It helped me to gain new } \\
\text { knowledge and skills I can apply } \\
\text { in my organization }\end{array}$ & 88 & 10 & 2 \\
\hline $\begin{array}{l}\text { I gained new professional } \\
\text { knowledge and skills that I can } \\
\text { share with my colleagues. }\end{array}$ & 98 & 2 & 0 \\
\hline $\begin{array}{l}\text { Training has increased my interest } \\
\text { in the subject }\end{array}$ & 90 & 6 & 4 \\
\hline $\begin{array}{l}\text { Having trainees from different } \\
\text { places increased my motivation }\end{array}$ & 95 & 4 & 1 \\
\hline $\begin{array}{l}\text { My PLC programming skills have } \\
\text { been increased }\end{array}$ & 88 & 10 & 2 \\
\hline $\begin{array}{l}\text { My HMI programming skills have } \\
\text { been increased }\end{array}$ & 88 & 10 & 2 \\
\hline
\end{tabular}

When the trainees' responses are examined, the percentage of those who marked the option of disagree was $2,5 \%$, the rate who chose the option to partially agree was $7,5 \%$, and the rate of those who chose the option of I agree was $90,0 \%$.

The study was evaluated on a group of 40 trainees and the performance of the groups of which all trainees participating in the course were members was evaluated so as to cover the period before and after the end of the course. The analysis results performed before and after the course were evaluated for all three groups. As the population we are working on consists of 40 people, no sampling was performed. The entire group which received education was taken into consideration. Also, non parametric hypothesis test was used depending on the 
number of staff in the studied group. First of all, the hl hypothesis, namely "There is a statistical difference between the education final scores for the groups which trainees are a part of." was tested. Kruskal Wallis test was used for the test and the analysis results are shown in Tab. 3. According to Tab. 3, it is observed that the tested hypothesis is correct. (Asymp. Sig. <\%5).

Table 3 Evaluation analysis results of the education

\begin{tabular}{|c|c|c|c|c|c|}
\hline \multicolumn{6}{|c|}{ Test statistics a, b } \\
\hline Type & $\mathrm{N}$ & $\begin{array}{c}\text { Mean } \\
\text { rank }\end{array}$ & Chi-square & df & $\begin{array}{l}\text { Asymp } \\
\text { sig. }\end{array}$ \\
\hline Technical Staff & 18 & 25,00 & \multirow{4}{*}{34,914} & \multirow{4}{*}{2} & \multirow{4}{*}{, 000} \\
\hline $\begin{array}{l}\text { Automation } \\
\text { Engineering Staff }\end{array}$ & 14 & 23,2 & & & \\
\hline $\begin{array}{l}\text { Prelicense } \\
\text { Training Staff }\end{array}$ & 8 & 4,56 & & & \\
\hline Total & 40 & & & & \\
\hline \multicolumn{6}{|c|}{ a. Kruskal Wallis Test } \\
\hline b. Grouping Varial & & & & & \\
\hline
\end{tabular}

As a result of the analysis, binary comparisons were conducted in order to observe which group caused the difference and the results are shown in Tabs. 4, 5 and 6 . (Mann-Whitney Test U was used in binary comparisons.) When the obtained results were examined, it was observed that there was no difference between employees in Technical Staff and the trainees receiving automation engineering education. (When Exact. Sig $>5 \% \mathrm{~h} 0$ hypothesis is accepted, in case of contrary h1 is accepted)

Table 4 Evaluation analysis results between industry staff and groups having automation engineering education.

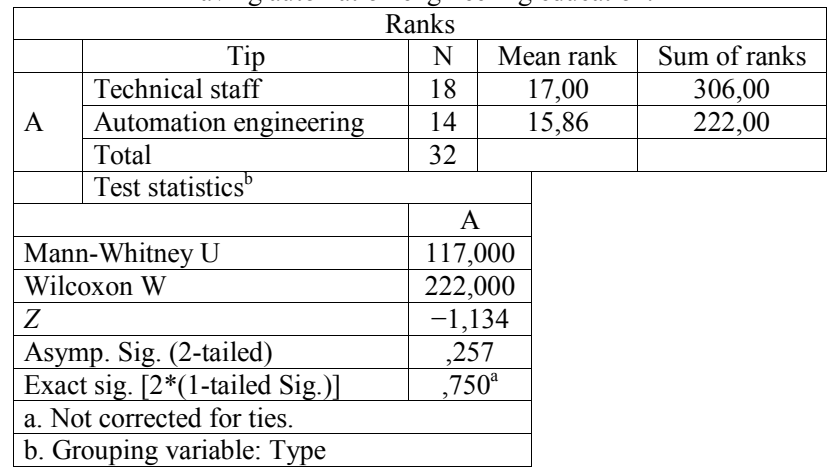

Table 5 Evaluation analysis results between industry staff and groups having associate degree education

\begin{tabular}{|c|c|c|c|c|}
\hline \multicolumn{5}{|c|}{ Ranks } \\
\hline & TIP & $\mathrm{N}$ & Mean rank & Sum of ranks \\
\hline \multirow{3}{*}{ A } & Technical staff & 18 & 17,50 & 315,00 \\
\hline & Prelicense training staff & 8 & 4,50 & 36,00 \\
\hline & Total & 26 & & \\
\hline \multicolumn{4}{|c|}{ Test statistics $^{\mathrm{b}}$} & \\
\hline & & \multicolumn{2}{|l|}{ A } & \\
\hline \multicolumn{2}{|c|}{ Mann-Whitney U } & \multicolumn{2}{|c|}{, 000} & \\
\hline \multicolumn{2}{|c|}{ Wilcoxon W } & \multicolumn{2}{|c|}{36,000} & \\
\hline \multicolumn{2}{|c|}{$\mathrm{Z}$} & \multicolumn{2}{|c|}{$-4,891$} & \\
\hline \multicolumn{2}{|c|}{ Asymp. sig. (2-tailed) } & \multicolumn{2}{|c|}{, 000} & \\
\hline \multicolumn{2}{|c|}{ Exact Sig. [2*(1-tailed Sig.)] } & \multicolumn{2}{|c|}{, $000 \mathrm{a}$} & \\
\hline \multicolumn{4}{|c|}{ a. Not corrected for ties. } & \\
\hline \multicolumn{4}{|c|}{ b. Grouping variable: TIP } & \\
\hline
\end{tabular}

The fact that there was a difference between employees working as technical staff and trainees having associate degree education and that there was a difference between those having automation engineering education and those having associate degree education are shown in Tabs. 5 and 6.
Table 6 Evaluation analysis results between groups having automation engineering and groups having associate degree education

\begin{tabular}{|c|c|c|c|c|}
\hline \multicolumn{5}{|c|}{ Ranks } \\
\hline & Type & $\mathrm{N}$ & & Sum of ranks \\
\hline \multirow{3}{*}{ A } & Automation Engineering & 14 & 15 & 216,50 \\
\hline & Prelicense Training Staff & 8 & 4 , & 36,50 \\
\hline & Total & 22 & & \\
\hline \multicolumn{4}{|c|}{ Test Statistics $^{\mathrm{b}}$} & \\
\hline & & \multicolumn{2}{|c|}{ A } & \\
\hline \multicolumn{2}{|c|}{ Mann-Whitney U } & \multicolumn{2}{|c|}{,500 } & \\
\hline \multicolumn{2}{|c|}{ Wilcoxon W } & \multicolumn{2}{|c|}{36,500} & \\
\hline \multicolumn{2}{|c|}{ Z } & \multicolumn{2}{|c|}{$-4,251$} & \\
\hline \multicolumn{2}{|c|}{ Asymp. Sig. (2-tailed) } & \multicolumn{2}{|c|}{, 000} & \\
\hline \multicolumn{2}{|c|}{ Exact Sig. [2*(1-tailed Sig.)] } & \multicolumn{2}{|c|}{, $000^{\mathrm{a}}$} & \\
\hline \multicolumn{4}{|c|}{ a. Not corrected for ties. } & \\
\hline \multicolumn{4}{|c|}{ b. Grouping Variable: Type } & \\
\hline
\end{tabular}

On the other hand, the analysis results performed according to trainee groups are shown in Tabs. 7 and 8. At this point, the proposed hypothesis namely "effect of education program before and after the course on trainees" and if it is effective "its effect in basis of groups" was tested.

Table 7 Evaluation analysis before and after the course

\begin{tabular}{|c|c|c|c|c|}
\hline \multicolumn{5}{|c|}{ Ranks } \\
\hline & & $\mathrm{N}$ & Mean rank & Sum of ranks \\
\hline \multirow[t]{4}{*}{ After- Before } & Negative ranks & $0^{\mathrm{a}}$ &, 00 &, 00 \\
\hline & Positive ranks & $31^{\mathrm{b}}$ & 16,00 & 496,00 \\
\hline & Ties & $9^{c}$ & & \\
\hline & Total & 40 & & \\
\hline \multicolumn{5}{|c|}{ a. After $<$ Before } \\
\hline \multicolumn{5}{|c|}{ b. After $>$ Before } \\
\hline \multicolumn{5}{|c|}{ c. After= Before } \\
\hline \multicolumn{5}{|c|}{ Test Statistics $^{\mathrm{b}}$} \\
\hline & \multicolumn{2}{|c|}{ After- Before } & \\
\hline \multicolumn{2}{|l|}{$Z$} & \multicolumn{2}{|r|}{$-5,568^{\mathrm{a}}$} & \\
\hline \multicolumn{2}{|c|}{ Asymp. Sig. (2-tailed) } & \multicolumn{2}{|r|}{, 000} & \\
\hline \multicolumn{4}{|c|}{ a. Based on negative ranks. } & \\
\hline \multicolumn{4}{|c|}{ b. Wilcoxon Signed Ranks Test } & \\
\hline
\end{tabular}

Table 8 Effect of education program before and after the course on basis of groups

\begin{tabular}{|c|c|c|c|c|c|}
\hline \multicolumn{6}{|c|}{ Ranks } \\
\hline \multicolumn{3}{|l|}{ Type } & $\mathrm{N}$ & $\begin{array}{l}\text { Mean } \\
\text { Rank }\end{array}$ & $\begin{array}{l}\text { Sum } \\
\text { of Ranks }\end{array}$ \\
\hline \multirow{4}{*}{$\begin{array}{l}\text { Technical } \\
\text { Staff }\end{array}$} & \multirow{4}{*}{$\begin{array}{l}\text { After } \\
\text { Before }\end{array}$} & Negative Ranks & $0^{2}$ & ,00 & , 00 \\
\hline & & Positive Ranks & $14^{\mathrm{b}}$ & 7,50 & 105,00 \\
\hline & & Ties & $4^{c}$ & & \\
\hline & & Total & 18 & & \\
\hline \multirow{4}{*}{$\begin{array}{l}\text { Automation } \\
\text { Engineering }\end{array}$} & \multirow{4}{*}{$\begin{array}{l}\text { After } \\
\text { Before }\end{array}$} & Negative Ranks & $0^{2}$ & , 00 &, 00 \\
\hline & & Positive Ranks & $11^{\mathrm{b}}$ & 6,00 & 66,00 \\
\hline & & Ties & $3^{c}$ & & \\
\hline & & Total & 14 & & \\
\hline \multirow{4}{*}{$\begin{array}{l}\text { Prelicense } \\
\text { Training } \\
\text { Staff }\end{array}$} & \multirow{4}{*}{$\begin{array}{l}\text { After } \\
\text { Before }\end{array}$} & Negative Ranks & $0^{2}$ &, 00 &, 00 \\
\hline & & Positive Ranks & $6^{b}$ & 3,50 & 21,00 \\
\hline & & Ties & $2^{c}$ & & \\
\hline & & Total & 8 & & \\
\hline \multicolumn{6}{|c|}{ a. After $<$ Before } \\
\hline \multicolumn{6}{|c|}{ b. After> Before } \\
\hline \multicolumn{6}{|c|}{ c. After= Before } \\
\hline \multicolumn{6}{|c|}{ Test Statistics $^{b}$} \\
\hline \multicolumn{5}{|l|}{ Type } & After-Before \\
\hline \multirow{2}{*}{\multicolumn{3}{|c|}{ Technical Staf }} & \multicolumn{2}{|l|}{$Z$} & $-3,742^{\mathrm{a}}$ \\
\hline & & & \multicolumn{2}{|c|}{$\begin{array}{l}\text { Asymp. Sig. } \\
\text { (2-tailed) }\end{array}$} &, 000 \\
\hline \multirow{2}{*}{\multicolumn{3}{|c|}{ Automation Engineering }} & \multicolumn{2}{|c|}{ Z } & $-3,317^{a}$ \\
\hline & & & \multicolumn{2}{|c|}{$\begin{array}{l}\text { Asymp. Sig. } \\
\text { (2-tailed) }\end{array}$} & ,001 \\
\hline \multirow{2}{*}{\multicolumn{3}{|c|}{ Prelicense Training Staff }} & \multicolumn{2}{|c|}{$\mathrm{Z}$} & $-2,449^{a}$ \\
\hline & & & \multicolumn{2}{|c|}{$\begin{array}{l}\text { Asymp. Sig. } \\
\text { (2-tailed) }\end{array}$} & 014 \\
\hline \multicolumn{6}{|c|}{ a. Based on negative ranks. } \\
\hline \multicolumn{6}{|c|}{ b. Wilcoxon Signed Ranks Test } \\
\hline
\end{tabular}

As observed in the analysis results in Tab. 7, as the Asymp. Sig. (2-tailed) value is smaller than $5 \%$ the 
hypothesis namely "effect of education program before and after the course on trainees" is accepted to be correct.

The analysis results related to the effect of the education program before and after the course on the basis of groups are shown in Tab. 8 .

According to Tab. 8, hypothesis was accepted for each group. When the findings obtained from analysis results were examined it was observed that the trainees employed as technical staff completed the course more efficiently. They were followed by the students having automation engineering education. Trainees having associate degree education were ranked last. The reason for that is interpreted as the lower (compared to the other two groups) theoretical and practical knowledge of trainees having associate degree education.

\section{Conclusion}

The best learning method for people working and studying in the automation field is 'try and see'. With the automation and control techniques training set, in addition to the training of HMI and PLC, essential elements of automation systems, programming, hardware installations, control techniques, and practical education are given. In the evaluation survey, the participants stated that in addition to hardware installation of PLC and HMI, their programming skills have been increased by $88,0 \%$. The study is also an example of applications within the framework of university-industry cooperation.

\section{References}

[1] Coşkun, İ.; Işık, M. F. Speed and Position Control of Servo Motor with Microprocessors. // Gazi University Journal of Science. 17, (2004), pp. 115-125.

[2] Yılmaz, C.; Gürdal, O.; Koşalay, İ. Network Induced Delay of Asynchronous Motor Connected to Profibus-DP Networks Using Fuzzy Logic Control Algorithm. // Expert System with Application. 37, 4(2010), pp. 3248-3255. DOI: 10.1016/j.eswa.2009.09.055

[3] Bartelt, T.; Industrial Control Electronics. United Kingdom: Thomson Delmar Learning, 2006.

[4] Bathunya, A. S.; Khopkar, R.; Wei, K.; Toliyat, H. A. Single phase induction motor drives - a literature survey. // In: IEEE 2001 International Electric Machines and Drives Conference / Cambridge, Massachusetts, USA, 2001, pp. 7803-7091.

[5] Tomiyama, T.; Gu, P.; Jin, Y.; Lutters, D.; Kind, C.; Kimura, F. Design methodologies: industrial and educational applications. // CIRP Ann - Manufacture Technology. 58, (2009), pp. 543-565. DOI: 10.1016/j.cirp.2009.09.003

[6] Hehenberger, P.; Poltschak, F.; Zeman, K.; Amrhein, W.; Hierarchical design models in the mechatronic product development process of synchronous machines. // Mechatronics. 20, (2010), pp. 864-875. DOl: 10.1016/..mechatronics.2010.04.003

[7] Gustavsson, I.; Remote Laboratory Experiments in Electrical Engineering Education. // Proceedings of the $4^{\text {th }}$ IEEE International Caracas Conference on Devices Circuits and Systems / Aruba, 2002, pp. I025/1- I025/5.

[8] Chang, T.; Hung, D. Web-Based Distance Experiments Design and Implementation. // International Conference on Engineering Education / Taiwan, 2000, pp. 1-5, 14-16.

[9] Harkin, J.; Callaghan, M. J.; Mc Ginnity, T. M.; Maguire, L. P. An Internet Based Remote Access Experimental
Laboratory for Embedded Systems. // IEE 2 nd Annual Symposium on Engineering Education / London, 2002, Ref. No. 2002/056.

[10] Sepe, Jr. R. B.; Chamberland, M.; Short, N. Web-Based Virtual Engineering Laboratory (VE-LAB) for a Hybrid Electric Vehicle Starter/Alternator. // IEEE Industry Applications Conference Thirty-Fourth IAS Annual Meeting / Phoenix, USA, Vol. 4, 1999, pp. 2642-2648. DOI: 10.1109/ias.1999.799210

[11] Huan-Wen, T. The Design of Pedagogical Agent for Distance Virtual Experiment. // $31^{\text {st }}$ ASEE/IEEE Frontiers in Education Conference/ Reno, 2001, pp. 18-23.

[12] Hong, W.; Vikram, K. Internet-Based Remote Control of a DC Motor Using an Embedded Ethernet Microcontroller. // Proceedings of the 2004 American Society for Engineering Education Annual Conference / Salt Lake City, Utah, USA, 2004, pp. 1329-1334.

[13] Chen, S. H.; Chen, R.; Ramakrishnan, V.; Hu, S. Y.; Zhuang, Y.; Ko, C. C.; Chen, Ben. M. Development of Remote Laboratory Experimentation through Internet. // Proceedings of the 1999 IEEE Hong Kong Symposium on Robotics and Control / Hong Kong, 1999, Vol. II, pp. 756760

[14] Maria, G. I. Design and implementation of plc-based monitoring control system for induction motor. // IEEE Trans. Energy Conversion. 3, (2004), pp. 469-476.

[15] Işık, M. F.; Coşkun, İ. Servo Control Education Tool for Industrial Applications. // Elektronika ir Elektrotechnika. 10, 106(2010), pp. 159-164.

[16] Yılmaz, C. İ.; Işı1k, M. F. Remote Controlling of DC Servomotor by way of Profibus-DP Network. $/ / 4^{\text {th }}$ FAE International Symposium / Cyprus, 2006, pp. 591-593.

[17] Keyhani, A.; Marwalli, M. N.; Higuera, L. E.; Athalye, G.; Baumgartner, G. An integrated virtual learning system for the development of motor drive systems. // IEEE Transactions on Power Systems. 17, (2002), pp. 1-6. DOI: 10.1109/59.982185

[18] Devitt, P.; Palmer, E. Computer-Aided learning: an overvalued educational resource? // Medical Education. 33, (1999), pp. 136-139. DOI: 10.1046/j.1365-2923.1999.00284.x

[19] Khongkoom, N.; Kanchanathep, A.; Nopnakeepong, S.; Tanuthong, S.; Tunyasrirut, S.; Kagawa, R. Control of The Position DC Servomotor by Fuzzy Logic. // TENCON 2000 / Kuala Lumpur, Vol. 3, 2000, pp. 354-357.

[20] Coşkun, İ.; Iş1k, M. F. Design and application of the technical training set for plc-based power supply unit developed for industrial applications. // Procedia-Social and Behavioral Sciences. 1, (2009), pp. 1658-1662. DOI: 10.1016/j.sbspro.2009.01.293

[21] Inc The Math Works. Matlab reference guide. Math Works, Incorporated, 1992.

[22] CX-Programmer Version. 9 WS02-CXPC1-V9, Operation Manual Function Blocks / Structured Text, Omron Cooperation, 2009.

\section{Authors' addresses}

\section{Mehmet Fatih Isik, Asst. Prof.}

Hitit University,

Faculty of Engineering, Electrical-Electronics Engineering, Cevre Yolu Bulvari No: 30, 19030, Corum/Turkey

E-mail:mehmetfatih@hitit.edu.tr 